\title{
A study of maternal near miss cases at tertiary medical college of Jharkhand, India
}

\author{
Samarina Kamal ${ }^{1 *}$, Priyankur Roy ${ }^{2}$, Shashibala Singh ${ }^{3}$, Jacinta Minz ${ }^{3}$
}

\begin{abstract}
${ }^{1}$ Department of Obstetrics and Gynecology, Alam Hospital, Ranchi, Jharkhand, India
${ }^{2}$ Department of Obstetrics and Gynecology, North Bengal Medical College, Siliguri, West Bengal, India

${ }^{3}$ Department of Obstetrics and Gynecology, Rajendra Institute of Medical Sciences, Jharkhand, India
\end{abstract}

Received: 15 April 2017

Accepted: 08 May 2017

\section{*Correspondence:}

Dr. Samarina Kamal,

E-mail: drsamrinakamal@gmail.com

Copyright: ( ) the author(s), publisher and licensee Medip Academy. This is an open-access article distributed under the terms of the Creative Commons Attribution Non-Commercial License, which permits unrestricted non-commercial use, distribution, and reproduction in any medium, provided the original work is properly cited.

\section{ABSTRACT}

Background: Maternal near miss is said to have occurred when women presented with life threatening complication during pregnancy, child birth and within 42 days after delivery, but survive by chance or good institutional care. For identifying near-miss cases five-factor scoring system was used. In 2009 WHO working group has standardized the criteria for selecting these cases.

Methods: The study was conducted in the Department of Obstetrics and Gynecology at RIMS, Ranchi, Jharkhand, India, which is a tertiary care centre. For each case of near miss, data were collected on demographic characteristics including gestational age at the time of sustaining the near-miss morbidity, nature of obstetric complications, presence of organ-system dysfunction/failure, ICU admission and timing of near-miss event with respect to admission.

Results: During the twenty-four months of the study period, 20000 deliveries at the institution and 480 women were identified as near-miss obstetrical cases by five factor scoring system. The prevalence of near-miss case in this study was $2.4 \%$. Near-miss per 1000 delivery was $24 \%$. Maternal death to near miss ratio was 1:7.2. The leading causes of maternal near miss were hemorrhage (42.5\%) and hypertensive disorder of pregnancy $(23.5 \%)$ The morbidity was high in unbooked cases.

Conclusions: Maternal near miss is good alternative indicator of health care system.

Keywords: High dependency unit, Intensive care unit, Maternal near miss, Relaparotomy

\section{INTRODUCTION}

Despite therapeutic advances during this century and a growing perception of the safety of child birth, morbidity and mortality continue to occur in obstetric patients. More than one woman dies every minute from such causes; 585,000 women die each year. In addition to maternal death, women experience more than 50 million maternal health problems annually. As many as 300 million women-more than one quarter of all adult women living in the developing world currently suffer from short of long term illness and injuries related to pregnancy and child birth. For every maternal death, there are many serious life. ${ }^{1-4}$ Threatening complications of pregnancy. Yet relatively little attention has been given to identifying a general category of morbidity that could be called nearmisses. Stones et al were the first to use the term "near miss morbidity" to define a narrow category of morbidity encompassing "potentiality life threatening episodes" 5,6

Maternal near miss is said to have occurred when women presented with life threatening complication during pregnancy, child birth and within 42 days after delivery, but survive by chance or good institutional care. Currently maternal near-miss ratio is increasingly used to evaluate the quality of obstetric care in low income 
countries. For identifying near-miss cases five-factor scoring system was used which has specificity of $93.9 \%$. It comprises of Organ-system failure, ICU admission, transfusion $>3$ units, extended intubation ( $>12$ hour) and surgical intervention (hysterectomy or relaparotomy). These factors are given the score of 5,4,3,2 and 1 respectively. A five-factor scoring system can theoretically have score from $0-15$ and the cut-off point is a score of 8 or greater. ${ }^{7}$

\section{Why Maternal Near Miss?}

- Near miss cases share many characteristics with maternal deaths and can directly inform on obstacles that had to be overcome after the onset of an acute complication.

- Corrective actions for identified problems can be taken to reduce related mortality and long-term morbidity.

Objectives of present study were to investigate various cases of near-misses and their incidence and influence on overall maternal mortality and to search the level of delay.

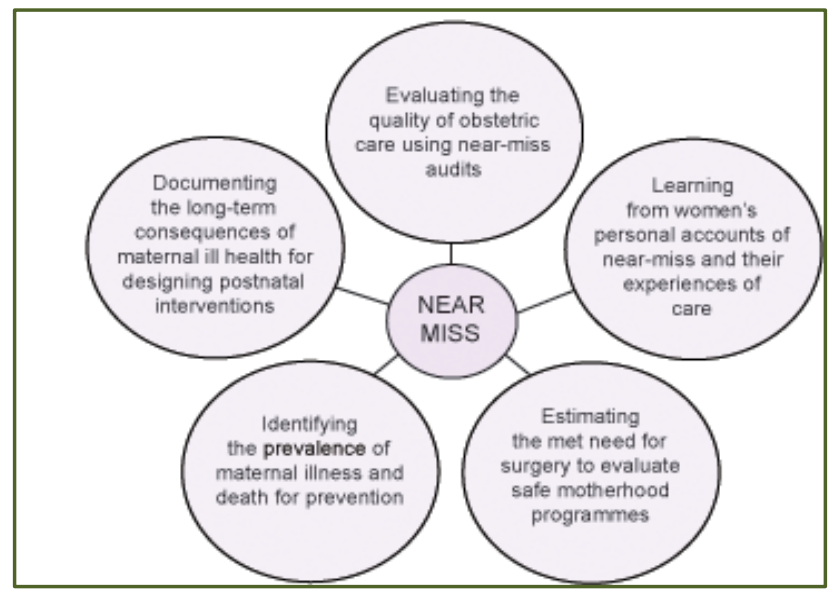

Figure 1: The uses of maternal near-miss in health research.

Table 1: Proposed WHO near-miss criteria.

\begin{tabular}{|c|c|c|}
\hline & Group A* & Group B* \\
\hline Cardiovascular dysfunction & $\begin{array}{ll}\text { - } & \text { Shock } \\
\text { - } & \text { Lactate }>5\end{array}$ & $\begin{array}{ll}\text { - } & \mathrm{pH}<7.1 \\
\text { - } & \text { Use of continuous } \\
& \text { vasoactive drugs } \\
\text { - } & \text { Cardiac arrest } \\
\text { - } & \text { Cardio-pulmonary } \\
& \text { resuscitation }(\mathrm{CPR})\end{array}$ \\
\hline Respiratory dysfunction & $\begin{array}{ll}\text { - } & \text { Acute cyanosis } \\
\text { - } & \text { Respiratory rate }>40 \text { or }<6 / \mathrm{min} \\
\text { Oxygen saturation }<90 \% \text { for } \geq \text { minutes }\end{array}$ & $\begin{array}{ll}\text { - } & \text { Gasping } \\
\text { - } & \mathrm{PaO} 2 / \mathrm{FiO} 2<20 \mathrm{mmHg} \\
& \text { Intubation and } \\
\text { ventilation not related to } \\
\text { anesthesia }\end{array}$ \\
\hline Renal dysfunction & Oliguria non-responsive to fluids or diuretics & $\begin{array}{l}\text { Creatinine } \geq 300 \mathrm{mmol} / 1 \\
\text { or } \geq 3,5 \mathrm{mg} / \mathrm{dl} \\
\text { - Dialysis for acute renal } \\
\text { failure }\end{array}$ \\
\hline $\begin{array}{l}\text { Coagulation } \\
\text { /haematological } \\
\text { dysfunction }\end{array}$ & $\begin{array}{l}\text { - Clotting failure } \\
\text { - Transfusion of } \geq 5 \text { units of blood / red } \\
\text { cells }\end{array}$ & $\begin{array}{l}\text { Acute thrombocytopenia }(<50 \\
000 \text { platelets })\end{array}$ \\
\hline Hepatic dysfunction & Jaundice in the presence of Pre-eclampsia & $\begin{array}{l}\text { Bilirubin }>100 \mathrm{mmol} / \mathrm{l} \text { or } 6,0 \\
\mathrm{mg} / \mathrm{dl}\end{array}$ \\
\hline Neurological dysfunctions & $\begin{array}{l}\text { - Metabolic coma (loss of consciousness } \\
\text { AND the presence of glucose and } \\
\text { ketoacids in urine) } \\
\text { - Stroke } \\
\text { - Status epilepticus / Uncontrollable fits / } \\
\text { total paralysis }\end{array}$ & $\begin{array}{l}\text { Coma / loss of consciousness } \\
\text { lasting } 12 \text { hours or more }\end{array}$ \\
\hline \multirow{2}{*}{ Urine dysfunction } & Hysterectomy due to infection or & \\
\hline & haemorrhage & \\
\hline
\end{tabular}




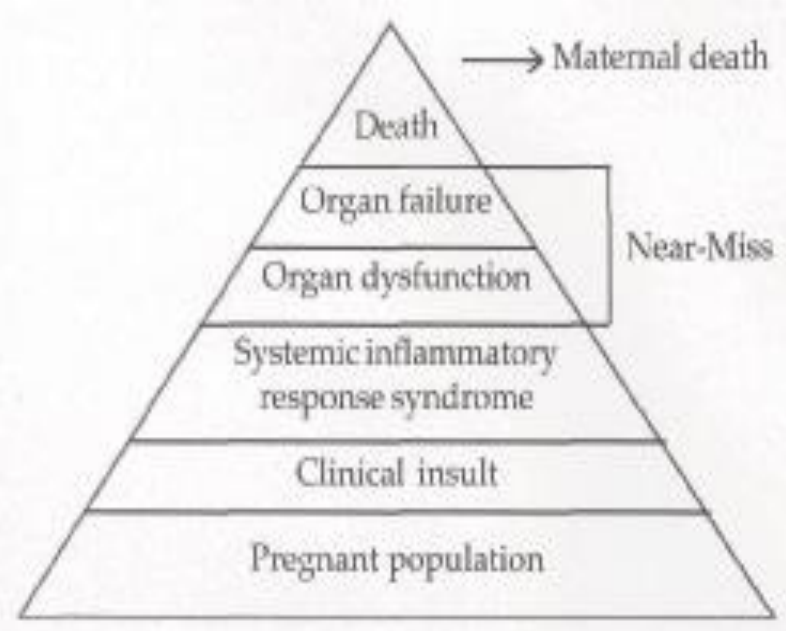

Figure 2: CBH criteria for potential cases of obstetric near-misses.

\section{METHODS}

\section{Place of study}

The study was conducted in the Department of Obstetrics and Gynaecology, RIMS, Ranchi, Jharkhand, India which is a tertiary care centre and serves as a referral centre for other Primary Health Centre and District hospitals of Jharkhand.

\section{Study Design}

This was a descriptive study done for the period of 24 months between October 2014 till October 2016. Cases of severe obstetric morbidity were identified during daily morning meetings, where all the new admission in the last 24 hour and serious inpatient cases were discussed. All the cases were followed during their hospital stay till their discharge or death. Five factor scoring system was used to identify the near miss cases from all the severe obstetric morbidity. For each case of near miss, data were collected on demographic characteristics including gestational age at the time of sustaining the near-miss morbidity, nature of obstetric complications, presence of organ-system dysfunction/failure, ICU admission and timing of near-miss event with respect to admission. Information during the study period were obtained from labour room and ICU/HDU registers.

\section{Data analysis}

Data were entered into a computer database using Microsoft Excel spreadsheet and statistical analysis was performed. The prevalence of near-miss cases is defined as the numbers of near-miss cases divided by the number of deliveries in the hospital. The frequencies of near-miss events are reported according to the clinical condition responsible, referral status of the patients and whether the complications were present upon arrival or occurred while on admission at the hospital.

\section{RESULTS}

During the twenty-four months of the study period, 20000 deliveries at the institution and 480 women were identified as near-miss obstetrical cases by five factor scoring system. The prevalence of near-miss case in this study was $2.4 \%$.

Table 2: Demographic characteristics of women with near-miss morbidity and maternal death.

\begin{tabular}{|ll|}
\hline Parity & Near-miss cases 480 \\
\hline 0 & $138(28.75 \%)$ \\
\hline $1-2$ & $250(52.08 \%)$ \\
\hline $3-4$ & $30(6.25 \%)$ \\
\hline$>5$ & $62(12.91 \%)$ \\
\hline Booking status & \\
\hline Unbooked at RIMS & $384(80 \%)$ \\
\hline Gestational age (weeks) & \\
\hline$<13$ & $80-16.6 \%$ \\
\hline $13-28$ & $36-7.5 \%$ \\
\hline$>28+$ Postpartum & $202+162(75.8 \%)$ \\
\hline
\end{tabular}

Table 3: Frequency and characteristics of near-miss cases.

\begin{tabular}{|ll|}
\hline Deliveries & 20000 \\
\hline Live birth & 18,426 \\
\hline Near miss & 480 \\
\hline Referred from other PHCs & $288(40 \%)$ \\
\hline On arrival & $250(52.08 \%)$ \\
\hline During hospitalization & $230(47.9 \%)$ \\
\hline
\end{tabular}

The demographic characteristics of the women classified as near-miss was median age- 27 (18-35), 138 (28.7\%) women were nulliparous. Majority of them were pare 12. $80 \%$ of the cases of near-miss were unbooked at RIMS. Prevalence of near-miss was highest in third trimester and postpartum period and was less in second trimester. $40 \%$ of the cases were referred from other hospitals in a critical care for ICU/HDU care. 52\% of the cases were critical on arrival to hospital. Near-miss per 1000 delivery was $24 \%$. maternal death to near miss ratio was 1:7.2.

204 cases of near miss were due to haemorrhage $(42.5 \%)$ of which 62 cases were due to rupture uterus. 28 cases were due to placenta previa, placenta accreta. Other cases were due to PPH out of which 10 cases were due to severe secondary PPH following caesarean delivery for which hysterectomy was required.

Hypertensive disorder of pregnancy was another important condition and accounted for $23.5 \%$ of cases. Cases of eclampsia received magnesium sulphate as anticonvulsant and were monitored in ICU. 48 cases were 
complications of septicaemia leading to multi organ failure 20 cases were due to cardiac failure out of which 4 cases were due to postpartum cardiomyopathy. Regarding the presence of different factors according to five factor scoring system, ICU admission was the most common factor followed closely by organ system failure. Total 67 cases suffered from organ system failure of which 7 cases had more than one organ/ system failure.

\section{Table 4: Diagnostic distributions of near-miss cases.}

\begin{tabular}{|ll|}
\hline Disease & Near-miss (n) \\
\hline Haemorrhage & 204 \\
\hline Early pregnancy & \\
\hline Ectopic & 20 \\
\hline Abortion & 26 \\
\hline Late pregnancy & \\
\hline Rupture uterus & 62 \\
\hline Placenta previa & 28 \\
\hline PPH & 68 \\
\hline Hypertension & 143 \\
\hline Eclampsia & 80 \\
\hline Severe preeclampsia & 63 \\
\hline Infections & 48 \\
\hline Others anaesthetic complication & 14 \\
\hline Cardiomyopathy & 4 \\
\hline Organ system failure & 67 \\
\hline
\end{tabular}

\section{DISCUSSION}

Near miss criteria were in vogue for some years, yet lack of uniformity was the hindrance. WHO criteria 2009 considered clinical as well as laboratory and management based criteria. Hence it incorporates both Mantel's and Waterston's criteria. The near miss rate was $2.4 \%$ in this study as against 4.4 per 1000 live births in a study from Brazil which used the new WHO criteria in an intensive care unit and MNMIR from India is reported to be 17.8/1000 live births. The maternal near miss incidence ratio is 24 per 1000 live births in this study, which is comparable to other studies done in developing countries show the same trend and vary between 15 to 40 per 1000 live births. The near miss to mortality ratio in our study is 7.2:1 which means for every 7.2 near miss cases, there was one maternal death. Higher ratios indicate better care. Syrian study showed 60:1 and study in Nepal showed a ratio of 7.2:1.

High income countries have reported a ratio of 117223:1.8 If this ratio increases over a period of time it reflects on the improvement achieved in the obstetric care. Maternal near miss mortality ratio is the ratio of number of cases of near miss to number of maternal deaths, higher ratio indicates better care. The analysis of maternal deaths has long been used for the evaluation of women's health and the quality of obstetric care. It has been suggested that with the observed decline in maternal mortality, analysis of well-defined near-miss cases may be a more sensitive measure of the standard of obstetric care. By Mantel GD et al, a near miss describes a patient with acute organ system dysfunction, which if not treated appropriately, could result in death. Prual A et al, has defined severe maternal morbidity as severe complications from 28 th week of gestation to $42^{\text {nd }}$ day postpartum that would have resulted in death of the mother or a definite invalidating sequela without medical intervention. Some studies have used intensive care unit (ICU) admissions to define near miss morbidity. According to Murphy DJ et al, all- women admitted for ICU in pregnancy or upto 42 day postpartum are considered as near-miss maternal mortality. By Pattinson RC et al, Severe Acute Maternal Morbidity (SAMM) also known as "near-miss" case means a woman with organ dysfunction or failure who would have died had it not been that luck or good care was on her side. During an international seminar held in Morocco, a near-miss case was defined as "any pregnant or recently delivered or aborted woman whose immediate survival is threatened and who survives by chance or because of the hospital care received In different studies, the primary obstetric causes of severe maternal morbidities have been found to be hypertensive disorders of pregnancy, massive obstetric haemorrhage and sepsis In an analogy with the study conducted by Roopa et al, women with 'near miss' outcome at gestational age 1-12, 13-28, >28weeks and postnatally were $17(12.9 \%), 6(4.6 \%), 75(57.2 \%)$ and $33(25.1 \%)$ respectively. The study findings for 'near miss's at 24-36 weeks and maternal death at >28 weeks corroborate our study findings. ${ }^{10-29}$

In another study conducted in Kathmandu by Shrestha et al, it was observed that pregnant women with gestational age of $<13,13-28,>28$ weeks and postpartum period who belonged to 'near miss's category were $11(30.5 \%), 6$ (16.66\%), $10(27.77 \%)$ and $9(25 \%)$ women respectively; A comparable study by Ranatunga et al from Srilanka found that majority $(57.1 \%)$ of 'near miss' cases were gravida G2-G4. Nelissen et al from Tanzania and Shreshta et al from Nepal also showed similar findings. However, Roopa et al showed in their study from South India that $56 . \%$ of the 'near miss' cases were of gravid status G1. Maternal mortality rate was an important indicator of the health care system.

As the rate declined in developed countries maternal near miss was considered and guidelines to select a patient under this category were given by WHO working group in due course assessment of health care facilities by maternal near miss was found to be equally effective Since then focus was shifted from maternal mortality to maternal near miss. Pacagnella RC, Cecatti JG et al found the incidence of potentially life threatening maternal conditions to be $11.6 \%$. A similar study done by Roopa PS, Shailja Verma et al found $10.3 \%$ incidence of potentially life threatening maternal condition. Maternal near miss incidence ratio has been 9.2 per 1000 live births. A study by Jayarathnam et al documented a ratio of 6 per 1000 live births. ${ }^{30,30-36}$ 


\section{CONCLUSION}

Lesson can be learned from cases of near-miss which can serve as a useful tool in reducing maternal mortality ratio. Need for development of an effective audit system for maternal care which includes both near-miss obstetric morbidity and mortality is felt.

\section{ACKNOWLEDGMENTS}

Authors are grateful to Dr. MAR Noon, Intensivist, Critical Care Alam hospital and Anesthesia department of RIMS, for their valuable suggestions coupled with profound knowledge on critical care of terminally ill obstetrics patients.

Funding: No funding sources Conflict of interest: None declared

Ethical approval: The study was approved by the Institutional Ethics Committee

\section{REFERENCES}

1. Atrash HK, Alexander S, Berg CJ. Maternal mortality in developed countries. Not Just a concern of the past. Obstet Gynaecol. 1995;86:700-5.

2. Revised 1990 Estimates of Maternal Mortality a New Approach WHO and UNICEF. World Health Organization, Geneva, 1996.

3. Healthy pregnancy and childbearing. In: Tsui AO, Wasserheit JN and Haaga JG eds. Reproductive Health in Developing countries: Expanding Dimensions, Building solutions, Washington DC, National Academy press, 1997.

4. The progress of Nations. UNICEF, New York, 1996.

5. Geller SE, Rosenberg D, Cox SM, Kilpatrick S. Defining a conceptual framework for near-miss maternal morbidity. J Am Med Womens Assoc. 2002;57(3):135-9.

6. Stones W, Lim W, Farook A, Kelly M. An investigation of maternal morbidity with the identification of life threatening "near-miss" episodes. Health trends. 1991;23:13-5.

7. WHO (2011)- Evaluating the quality of care for severe pregnancy complications: The WHO Near Miss Approach for maternal health. World Health Organization.

8. Geller SE, Rosenberg D, Cox S, Brown M, Simonson L, Kilpatrick S. (2004) A scoring system identified near-miss maternal morbidity during pregnancy. J Clin Epi. 57:716-20.

9. World Health Organization, UNICEF, UNFPA and The World Bank. Trends in maternal mortality: 1990 to 2008. Geneva: World Health Organization, 2010.

10. Say L, Souza JP, Pattinson RC. Maternal near misstowards a standard tool for monitoring quality of maternal health care. Best Pract Res. 2009;23(3):287-96.
11. Mantel GD, Buchmann E, Rees H. Severe acute maternal morbidity. British J Obstet Gynaecol. 1998;105(9):985-90.

12. Waterstone M, Wolfe C, Bewley S. Incidence and pre-dictors of severe obstetric morbidity: casecontrol study. British Med J. 2001;322(7294):108993.

13. Lotufo FA, Parpinelli MA, Haddad SM, Surita FG. Applying the new concept of maternal near-miss in an intensive care unit, Clinics. 2012;67(3):225-30.

14. Roopa PS, Verma S, Rai L, Kumar P, Pai MV, Shetty J. "Near Miss" Obstetric Events and Maternal Deaths in a Tertiary Care Hospital: An Audit. J pregnancy. 2013.

15. Roosmalen VJ, Zwart J. Severe acute maternal morbidity in high-income countries. Best Prac Res: Clin Obstet Gynaecol. 2009;23(3):297-304.

16. Souza JP, Cecatti JG, Parpinelli MA, Serruya SJ, Amaral E. Appropriate criteria for identification of near-miss maternal morbidity in tertiary care facilities: a cross sectional study. BMC Pregnancy Childbirth. 2007;7(20):1-8.

17. Shrestha NS, Saha R, Karki C. Near miss maternal morbidity and maternal mortality. Kathmandu University. Med J. 2010;8(30):222-26.

18. Almerie Y, Almerie MQ, Matar HE, Shahrour Y. Obstetric near-miss and maternal mortality in maternity university hospital, Damascus, Syria. BMC Pregnancy Childbirth. 2010;10:65-8.

19. Evaluating the quality of care for severe pregnancy complications: the WHO near-miss approach for maternal health. Geneva: World Health Organization; 2011.

20. Cham M, Sundby J, Vangen S. Availability and quality of emergency obstetrics care in Gambia's main referral hospital: Women-users' testimonies. Reprod Health. 2009;6:5.

21. Minkauskiene M. Incidence/prevalence of severe maternal morbidity: A literature review. Geneva: Geneva Foundation for Medical Education and Research. Available at: http: www. gfmer. chEndoCourse2003Severe_maternal20morbidity_rev iew. htm. 2003.

22. Bewley S, Creighton S. "Near-miss" obstetric enquiry. J Obstet Gynaecol (Paris). 1997;17:26-9.

23. Drife JO. Maternal near-miss reports? BMJ. 1993;307:1087-8.

24. Mantel GD, Buchmann E, Rees H, Pattinson RC. Severe acute maternal morbidity: A pilot study of a definition for a near miss. Br. J obstet Gynaecol. 1998;105:985-90.

25. Prual A, Bouvier -Colle MH, De Bernis L, Breart G: Severe maternal morbidity from direct obstetric causes in West Africa: Incidence and case fatality rates Bull World Health Organ. 2000;78:593-602.

26. Baskett TF, Sternadel J. Maternal intensive care and near miss mortality in obstetrics Br. J obstet Gynacecol. 1998;105:981-4.

27. Murphy DJ, Charlett P. Cohort study of near miss maternal mortality and subsequent reproductive 
onteome. Eur J. obstet Gynaecol Reprod Biol. 2002;102:173-8.

28. Pattinson RC, Vandecruys HI, Macdonald AP, Mantel GD. Why do women die during childbirth. Science in Africa Available at: URL: http://www. scienceinafrica. co. za/2001/august/mothers. htm. 2001.

29. Ranatunga GA, Akbar JF, Samarathunga S, Perera YAG, Kariyawasam L, Kumarasiri JM. Severe acute maternal morbidity in a tertiary care institution. Sri Lanka J Obstet Gynaecol. 2012;34:135-43.

30. Nelissen EJ, Mduma E, Ersdal HL, Evjen-Olsen B, van Roosmalen JJ, Stekelenburg J. Maternal near miss and mortality in a rural referral hospital in northern Tanzania: a crossectional study. BMC Pregnancy Childbirth. 2013;13:141.

31. Shrestha NS, Saha R, Karki C. Near miss maternal morbidity and maternal mortality at Kathmandu Medical College Teaching Hospital. Kathmandu Univ Med J. 2010;8(2):222-6.

32. Say L, Pattinson RC, Gülmezoglu AM. WHO systematic review of maternal morbidity and mortality: the prevalence of severe acute maternal morbidity (near miss). Reprod Health. 2004;1(1):109.
33. Pattinson RC, Hall M. Near misses: a useful adjunct to maternal death enquiries. $\mathrm{Br}$ Med Bull. 2003;67:231-43.

34. Pacagnella RC, Cecatti JG, Parpinelli MA, Sousa $\mathrm{MH}$. Delays in receiving obstetric care and poor maternal outcomes: results from a national multicentre cross-sectional study. BMC Pregnancy Childbirth. 2014;14:159.

35. Roopa PS, Verma S, Rai L, Kumar P, Murlidhar V, Pai, et al. "Near Miss" Obstetric Events and Maternal Deaths in a Tertiary Care Hospital: An Audit Journal of Pregnancy. (2013).

36. Jayaratnam S, Costa C D, Howat P. Developing an assessment tool for maternal morbidity 'near-miss'A prospective study in a large Australian regional hospital. Australian New Zealand J Obstet Gynaecol. 2011;51(5):421-5.

Cite this article as: Kamal S, Roy $\mathrm{P}$, Singh S, Minz J. A study of maternal near miss cases at tertiary medical college of Jharkhand India. Int J Reprod Contracept Obstet Gynecol 2017;6:2375-80. 